\title{
Compliant Foil Journal Bearing Performance at Alternate Pressures and Temperatures
}

Robert J. Bruckner and Bernadette J. Puleo

Glenn Research Center, Cleveland, Ohio 


\section{NASA STI Program . . . in Profile}

Since its founding, NASA has been dedicated to the advancement of aeronautics and space science. The NASA Scientific and Technical Information (STI) program plays a key part in helping NASA maintain this important role.

The NASA STI Program operates under the auspices of the Agency Chief Information Officer. It collects, organizes, provides for archiving, and disseminates NASA's STI. The NASA STI program provides access to the NASA Aeronautics and Space Database and its public interface, the NASA Technical Reports Server, thus providing one of the largest collections of aeronautical and space science STI in the world. Results are published in both non-NASA channels and by NASA in the NASA STI Report Series, which includes the following report types:

- TECHNICAL PUBLICATION. Reports of completed research or a major significant phase of research that present the results of NASA programs and include extensive data or theoretical analysis. Includes compilations of significant scientific and technical data and information deemed to be of continuing reference value. NASA counterpart of peer-reviewed formal professional papers but has less stringent limitations on manuscript length and extent of graphic presentations.

- TECHNICAL MEMORANDUM. Scientific and technical findings that are preliminary or of specialized interest, e.g., quick release reports, working papers, and bibliographies that contain minimal annotation. Does not contain extensive analysis.

- CONTRACTOR REPORT. Scientific and technical findings by NASA-sponsored contractors and grantees.

- CONFERENCE PUBLICATION. Collected papers from scientific and technical conferences, symposia, seminars, or other meetings sponsored or cosponsored by NASA.

- SPECIAL PUBLICATION. Scientific, technical, or historical information from NASA programs, projects, and missions, often concerned with subjects having substantial public interest.

- TECHNICAL TRANSLATION. Englishlanguage translations of foreign scientific and technical material pertinent to NASA's mission.

Specialized services also include creating custom thesauri, building customized databases, organizing and publishing research results.

For more information about the NASA STI program, see the following:

- Access the NASA STI program home page at http://www.sti.nasa.gov

- E-mail your question via the Internet to help@ sti.nasa.gov

- Fax your question to the NASA STI Help Desk at 301-621-0134

- Telephone the NASA STI Help Desk at 301-621-0390

- Write to: NASA Center for AeroSpace Information (CASI) 7115 Standard Drive Hanover, MD 21076-1320 
NASA/TM-2008-215219

GT2008-50174

\section{Compliant Foil Journal Bearing Performance at Alternate Pressures and Temperatures}

Robert J. Bruckner and Bernadette J. Puleo

Glenn Research Center, Cleveland, Ohio

Prepared for the

Turbo Expo 2008 Gas Turbine Technical Congress and Exposition sponsored by the American Society of Mechanical Engineers

Berlin, Germany, June 9-13, 2008

National Aeronautics and

Space Administration

Glenn Research Center

Cleveland, Ohio 44135 


\section{Acknowledgments}

The work presented in this paper was funded under the NASA Fundamental Aeronautics ProgramSubsonic Rotary Wing Propulsion Program

This report is a preprint of a paper intended for presentation at a conference.

Because changes may be made before formal publication, this preprint is made available with the understanding that it will not be cited or reproduced without the permission of the author.

This work was sponsored by the Fundamental Aeronautics Program at the NASA Glenn Research Center.

Level of Review: This material has been technically reviewed by technical management.

Available from

NASA Center for Aerospace Information 7115 Standard Drive

Hanover, MD 21076-1320
National Technical Information Service 5285 Port Royal Road Springfield, VA 22161 


\title{
Compliant Foil Journal Bearing Performance at Alternate Pressures and Temperatures
}

\author{
Robert J. Bruckner and Bernadette J. Puleo \\ National Aeronautics and Space Administration \\ Glenn Research Center \\ Cleveland, Ohio 44135
}

\begin{abstract}
An experimental test program has been conducted to determine the highly loaded performance of current generation gas foil bearings at alternate pressures and temperatures. Typically foil bearing performance has been reported at temperatures relevant to turbomachinery applications but only at an ambient pressure of one atmosphere. This dearth of data at alternate pressures has motivated the current test program. Two facilities were used in the test program, the ambient pressure rig and the high pressure rig. The test program utilized a $35 \mathrm{~mm}$ diameter by $27 \mathrm{~mm}$ long foil journal bearing having an uncoated Inconel X-750 top foil running against a shaft with a PS304 coated journal. Load capacity tests were conducted at $3,6,9,12,15,18$, and $21 \mathrm{krpm}$ at temperatures from 25 to $500{ }^{\circ} \mathrm{C}$ and at pressures from 0.1 to 2.5 atmospheres. Results show an increase in load capacity with increased ambient pressure and a reduction in load capacity with increased ambient temperature. Below one-half atmosphere of ambient pressure a dramatic loss of load capacity is experienced. Additional lightly loaded foil bearing performance in nitrogen at $25{ }^{\circ} \mathrm{C}$ and up to 48 atmospheres of ambient pressure has also been reported. In the lightly loaded region of operation the power loss increases for increasing pressure at a fixed load. Knowledge of foil bearing performance at operating conditions found within potential machine applications will reduce program development risk of future foil bearing supported turbomachines.
\end{abstract}

\section{Introduction}

The discovery of the compliant foil journal bearing was initially reported by Blok and VanRussom (ref. 1) in 1953. These bearings are self-acting hydrodynamic bearings having the unique feature of a compliant surface. A representation of a compliant foil journal bearing is shown in figure 1. The main features of these bearings include a rigid sleeve (or bearing housing), a compliant foundation provided by either overlapping leaves or bump foils, the hydrodynamic surfaces of the top foil, and the rotating journal. When stationary, the top foils are preloaded against the journal, which is a departure from traditional hydrodynamic bearings that are characterized by a fixed clearance between the rotating and stationary components. However, even at relatively low rotational speeds, hydrodynamic lubrication quickly builds a gas pressure that acts against the compliant foundation and separates the two moving surfaces. This provides a low friction and maintenance-free rotor support system. These bearings can offer many advantages to high speed turbomachines. These benefits primarily arise from the elimination of an oil system and the associated weight and maintenance burden. Additional benefits may be achieved from the elimination of temperature and rotating speed limits that are found on traditional oil-lubricated bearings. The resulting rotor support system having no oil lubricated and cooled components has become known as "Oil-Free Turbomachinery".

Over the first four decades of foil bearing development these bearings were applied to several types of turbomachines. These applications were characterized by ambient pressure, low temperature, and lightly loaded conditions in centrifuges, cryogenic pumps, and aircraft air cycle machines. Recent advances in foil bearing load capacity and high temperature solid lubricant coatings have broadened the scope of potential applications. Microturbines for distributed power generation are commercially available products as are industrial oil-free compressors and blowers. Oil-free turbojet engines and turbochargers have been demonstrated, while development programs are underway to utilize foil bearings in larger aircraft engines. Future applications that are under consideration are microturbines for closed Brayton cycle power generation systems (ref. 2). One impediment to more widespread use of foil bearings in high speed turbomachines is the general lack of understanding of foil bearing performance at off-design speeds and at relevant ambient pressures and temperatures. Knowledge at both low and high pressures is necessary to provide preliminary guidance for future oil-free turbomachines. Current foil bearing size selection stems from the use of the design generation designation of DellaCorte (ref. 3). However, additional information is required, such as off-design performance, to design the optimum rotor support structure. For example, if one considers a ground-based open Brayton cycle microturbine sized for $30 \mathrm{~kW}$ of electrical output, the foil bearings could account for $1.6 \mathrm{~kW}$ of power loss. Bearings designed in such a manner could still possess adequate performance in terms of rotor support. However a more appropriate size selection based on actual ambient conditions found in the machine could reduce this power loss by an order of magnitude. Not only would this knowledge benefit the overall system thermodynamic performance, but it would also provide greater life and durability for the engine. 

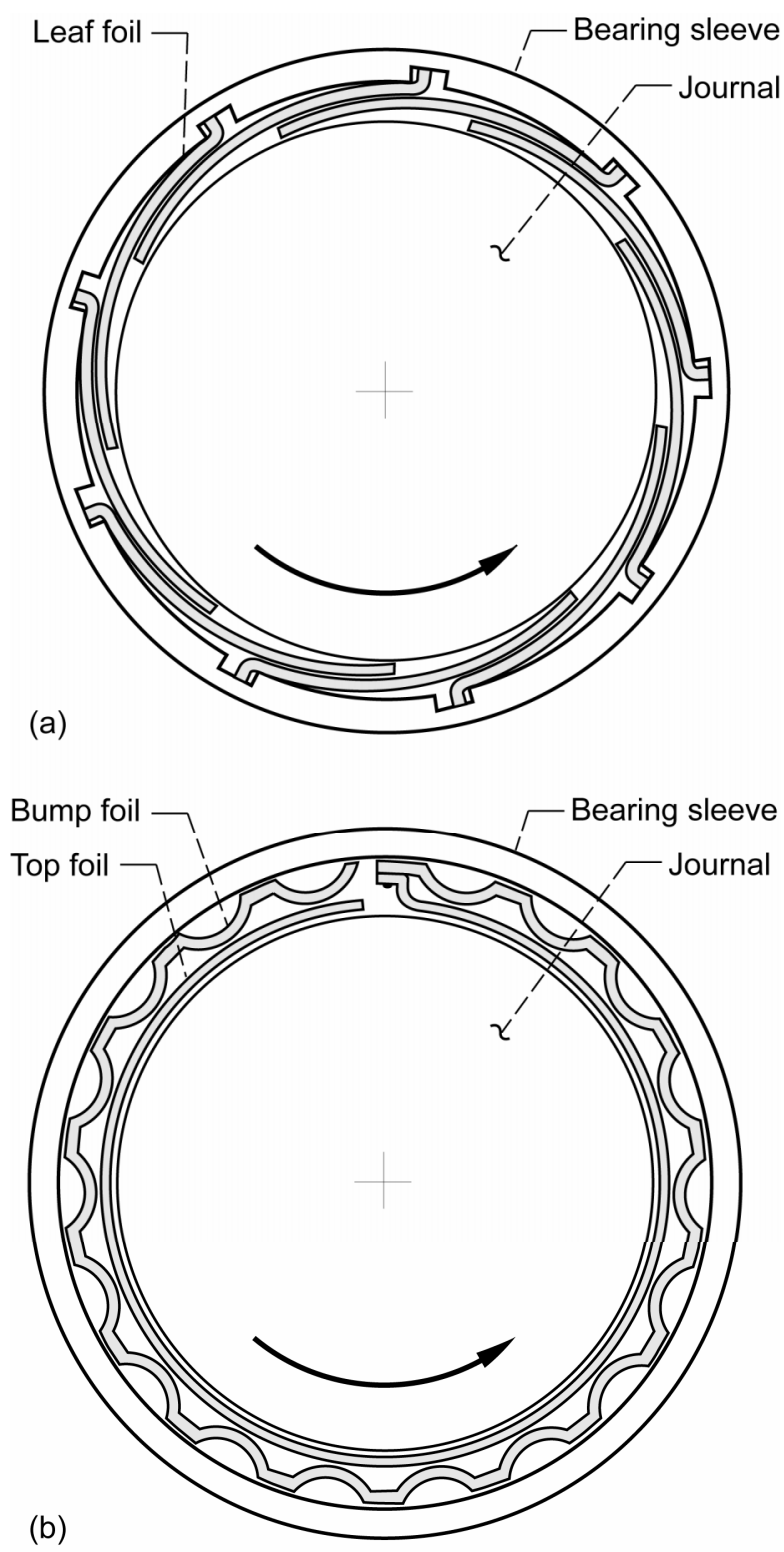

Figure 1.-Early foil bearing designs. (a) Leaf-type foil bearing. (b) Bump-type foil bearing.

Because gas foil bearing performance is a highly coupled phenomenon comprised of large structural deformations, tribology, hydrodynamics, and fluid properties an experimental approach is taken towards furthering the understanding of the effects of ambient environment on foil bearing performance. Experimental performance has been measured on two research rigs, the ambient pressure rig and the high pressure rig. Each of these rigs has a unique capability. The ambient pressure rig is capable of measuring load capacity at pressures and temperatures up to 2.5 atmospheres and $500{ }^{\circ} \mathrm{C}$, respectively. The high pressure rig is capable of measuring lightly loaded bearing performance at pressures and speeds up to 48 atmospheres and 42,000 revolutions per minute, respectively. The experimental results presented herein can be explained through the use of the foil bearing performance map (ref. 4). The basic performance map in three dimensions plots bearing power loss versus shaft speed and unit load. In this perspective the foil bearing exhibits a proportional trend with load and a parabolic trend in speed where a power loss minimum may be identified. The performance trends found in the current test program indicate that pressure and temperature effects can best be described as a translation along the rotational speed axes on the foil bearing performance map.

\section{Nomenclature}

D Load capacity coefficient, $\mathrm{mN} /\left(\mathrm{mm}^{3} \mathrm{krpm}\right)$

[lbf/(in. $\left.\left.{ }^{3} \mathrm{krpm}\right)\right]$

W Load supported by foil bearing, $\mathrm{N}$ [lbf]

D Diameter of journal, $\mathrm{mm}$ [in.]

L Length of bearing, $\mathrm{mm}$ [in.]

$\mathrm{N}$ rotational speed, kilo-revolutions per minute (krpm)

$\mathrm{P}$ ambient pressure of bearing cavity, atm

$\mathrm{T}$ ambient temperature of bearing cavity, ${ }^{\circ} \mathrm{C}$
Subscripts
pl preload
$\mathrm{t}$ total
$\mathrm{dw}$ deadweight

\section{Foil Bearing Description}

Foil gas bearings are compliant surface, self-acting hydrodynamic bearings that use ambient gas as their working fluid or lubricant. They do not require external pressurization and are typically constructed from several layers of sheet metal foils from which they derive their name. The reader is again referred to figure 1 which shows examples of early style journal bearings. The top bearing in figure 1 is commonly referred to as an overlapping leaf design while the lower bearing is a bump foil design. These names stem from the design and architecture of the compliant layer beneath the top foil. This innermost foil, top foil, serves as the hydrodynamic surface that traps the high pressure gas film between it and the rotating shaft. Foil bearings are used in many lightly loaded, high-speed turbomachines such as compressors used for aircraft pressurization and micro-turbines. Foil gas bearings provide a means to eliminate the oil system leading to lower system weight and enhanced temperature capability. Additionally, the elimination of the oil system can lead to a maintenance-free machine. Under static conditions the top foil is preloaded against the shaft, $\mathrm{W}_{\mathrm{pl}}$, such that there is no static clearance or eccentricity between the stationary and rotating parts. This is a fundamental difference between the foil bearing and rigid hydrodynamic bearings and gives rise to additional parameters required to characterize these bearings (ref. 5). Additionally, the design generation or load capacity coefficient is a third parameter that characterizes a foil journal 
bearing. Dellacorte (ref. 3) identifies a design classification scheme that correlates compliant foundation complexity with bearing load capacity. A generation I design consists of a uniform stiffness foundation and is typical of early foil bearings. Generation II bearings vary the compliant foundation in one direction, for example in the axial or circumferential direction. Generation III bearings vary the compliant foundation in at least two directions. DellaCorte goes on to quantify the load capacity of foil journal bearings according to equation (1). In the steady state performance testing of foil bearings great care is taken to minimize all applied loads other than the preload and deadweight load such that the total load is known very accurately. The performance coefficient is typically $0.08,0.19$, and $0.27 \mathrm{mN} /\left(\mathrm{mm}^{3} \mathrm{krpm}\right)$ [0.3, 0.7, and $\left.1.0 \mathrm{lbf} /\left(\mathrm{in} .{ }^{3} \mathrm{krpm}\right)\right]$ for generation I, II, and III bearings respectively.

$$
\begin{aligned}
& \mathrm{W}_{\mathrm{t}}=\mathcal{D}(\mathrm{L} \times \mathrm{D})(\mathrm{D} \times \mathrm{N}) \\
& \mathrm{Where} \\
& \mathrm{W}_{\mathrm{t}}=\mathrm{W}_{\mathrm{pl}}+\mathrm{W}_{\mathrm{dw}}+\mathrm{W}_{\text {dynamic }}+\mathrm{W}_{\text {thermal }}+\ldots . .
\end{aligned}
$$

For the foil bearings used in this test program, typical values for friction coefficient, preload and load capacity coefficient measured at room temperature and ambient pressure are $0.45,3.7 \mathrm{kPa}[0.54 \mathrm{psi}]$, and $0.27 \mathrm{mN} /\left(\mathrm{mm}^{3} \mathrm{krpm}\right)$ [1.0 lbf/(in. $\left.\left.{ }^{3} \mathrm{krpm}\right)\right]$. The friction coefficient is quite high, especially considering that low friction is desirable for this application. This high value is caused because only materials suitable for high temperature applications are used. The foil bearings use uncoated Inconel top foils and the shaft is coated with PS304, a high temperature solid lubricant (refs. 6 and 7). Lower friction coefficients may be obtained for low temperature applications by using highly polished shaft surfaces with thin dense chrome plating and organic polymer coated topfoils.

\section{Foil Bearing Applications}

Although originally discovered in the early 1950s gas foil bearing technology first developed for use in turbomachinery in the 1960s to support high speed rotating shaft systems that could not operate using conventional oil-lubricated bearings or rigid geometry gas bearings due to contamination, speed and thermal stability requirements (refs. 8 to 10 ). Foil bearings have evolved to the point where they are in commercial use in specialized applications such as air cycle machines, turboexpanders and compressors, and small micro-turbine systems (refs. 11 and 12). Foil bearings have also been demonstrated as "proof of concepts" in diesel engine turbochargers, auxiliary power units, expendable turbojet engines, and selected hot section bearings in gas turbine engines (refs. 13 to 15).

The implementation of foil bearings to new applications requires an understanding of foil bearing operation at a variety of operating conditions. Figure 2 shows several candidate Brayton cycle applications along with various single-spool

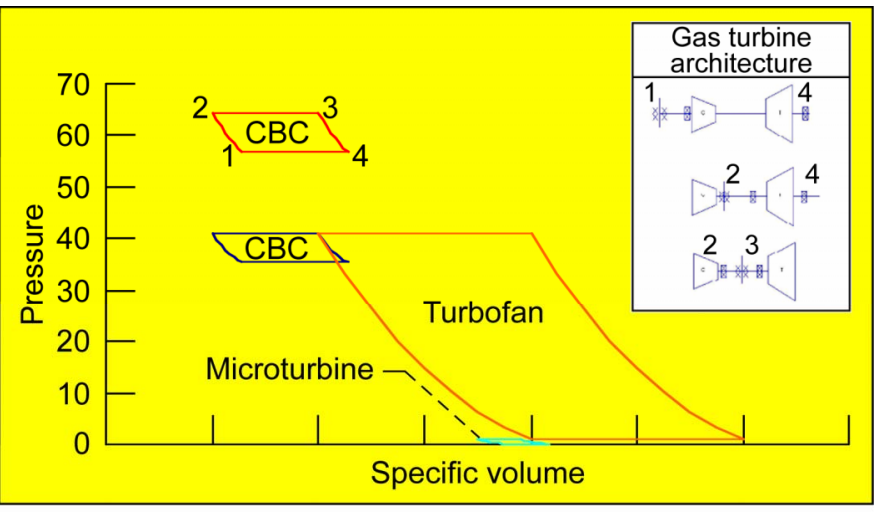

Figure 2.--Representative Brayton cycles and turbomachinery architectures.

architectures that could be used with these cycles. In addition to high pressure and temperature conditions found in the central region of a Brayton cycle machine, potential high altitude aeronautical applications require low pressure operating characteristics to be understood. Examination of the cycles and architectures in figure 2 indicates that in order to make strategic decisions in the conceptual design phase, the machine designer requires knowledge of foil bearing sizing and operation over an extremely large range of pressures and temperatures. The current test program has investigated the behavior of foil bearings in the highly loaded region (near load capacity) as a function of temperature from ambient conditions to $500{ }^{\circ} \mathrm{C}$ and pressure from 0.1 atmospheres to 2.5 atmospheres in air. Additionally, limited data of lightly loaded foil bearings in pressures up to 48 atmospheres has been analyzed in this study. The current study is intended to provide design guidance at the system level to bound the sizing and performance of foil bearings at various operating conditions. An experimental approach is taken in this study because foil bearings are somewhat poorly understood analytically and there are currently no non-empirical, predictive design tools that can be used to accurately determine foil bearing performance over such a wide range of loads, pressures, temperatures, and speeds.

\section{Test Rigs and Procedures}

The primary test rig used in generating the current database is the ambient pressure rig. The rig is shown in figure 3 . The rig consists of a motor driven spindle and journal capable of speeds up to $30,000 \mathrm{rpm}$. A furnace can enclose the test bearing and journal. Testing can be conducted at temperatures up to $500{ }^{\circ} \mathrm{C}$. A pneumatic loader is used to apply variable loads in excess of failure loads for a generation III foil bearing. A precision load cell mounted outside of the furnace measures bearing reaction torque. The entire test rig is enclosed in an aluminum chamber. This chamber can be evacuated to 0.1 atmospheres and pressurized to 2.5 atmospheres. A variety of inert gases can be used in this test 

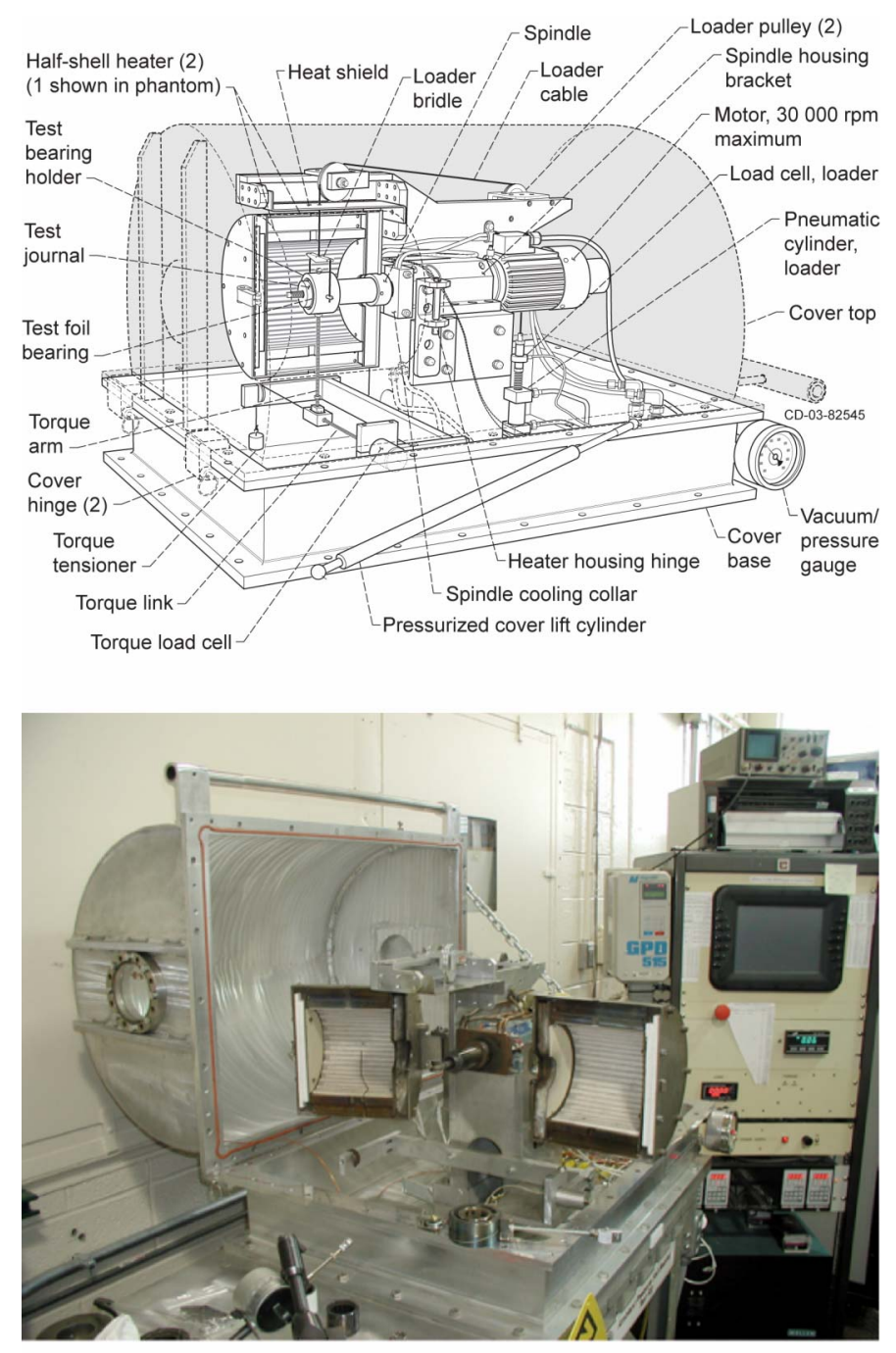

Figure 3.-The ambient pressure rig.

rig to investigate gas property effects on foil bearing performance. For the current test program only air has been used as a foil bearing lubricant. Generation III foil journal bearings with uncoated Inconel top foils running against conditioned PS304 high temperature solid lubricant coated shafts were used in this study. The test procedure used on this rig includes a preliminary conditioning of the PS304 coated shaft which includes running 500 start-stop cycles under load at high temperature to develop a highly polished, smooth, and lubricious hydrodynamic surface on the shaft. This conditioning procedure also transfers solid lubricants from the shaft coating to the top foil. Once the foil bearing and shaft have been properly characterized and conditioned, performance testing was conducted. The performance tests are conducted at constant speed, temperature, and pressure. Once these conditions are set and stable, the radial load was applied to the bearing. The load was increased in steps while the reaction torque is monitored on the data acquisition system. Figure 4 shows a typical time trace of such a performance test
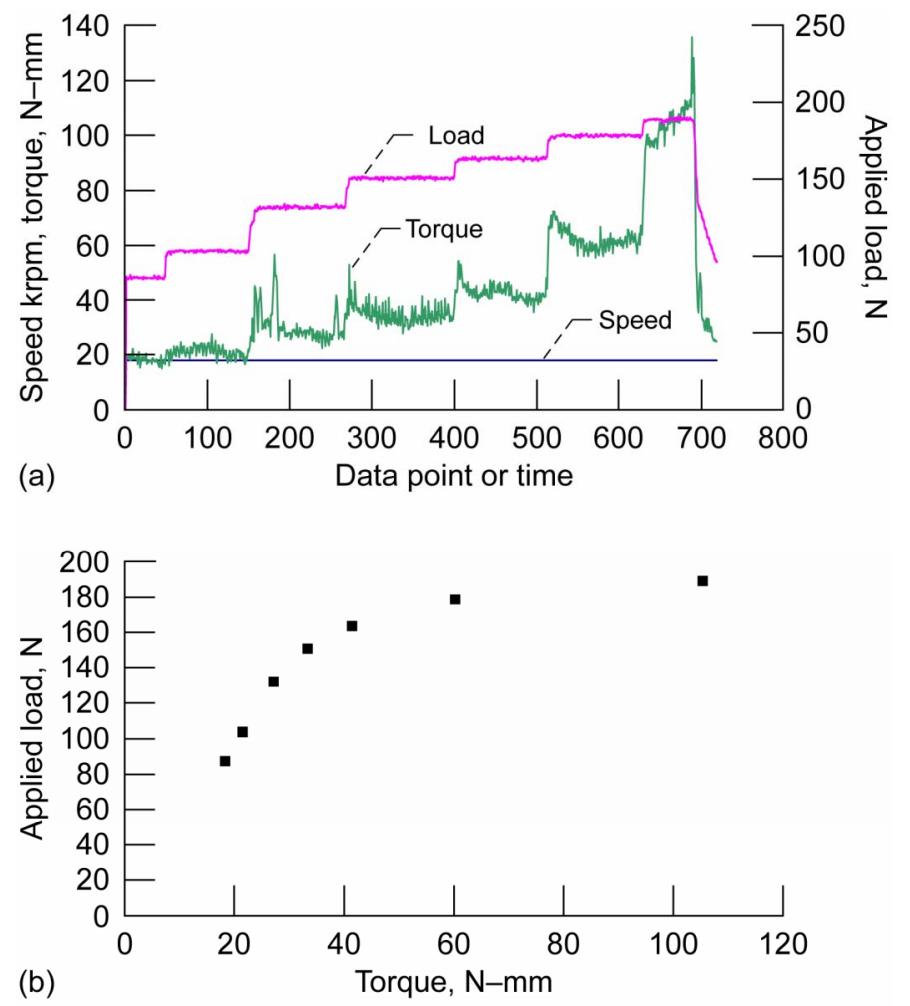

Figure 4.-(a) Typical time trace from the ambient pressure.

(b) The resultant load-torque characteristic.

as well as the resultant load - torque characteristic of the bearing at the test conditions. The load, and hence reaction torque, continue to increase until the gas film is no longer able to support the load. This condition is indicated when the reaction torque rises sharply with a modest increase in radial load. The resultant data can then be analyzed to determine the load capacity and load - torque characteristic of the foil bearing at a given operating condition. The load capacity is typically determined by averaging the incipient film rupture and post load capacity points (the two points in the upper right in figure 4(b)).

A second rig used in this study is the high pressure rig. The rig is shown in figure 5 . The rig is a simplification of the ambient pressure rig. The simplifications were made in order to certify the rig to extremely high pressure, up to 48 atmospheres. The rig consists of a motor driven spindle and journal capable of speeds up to $42,000 \mathrm{rpm}$. Testing is limited to $38^{\circ} \mathrm{C}\left[100{ }^{\circ} \mathrm{F}\right.$ ]. Radial loading is accomplished by placing balanced annular weights over the journal, as such the maximum load that can be tested in this rig is approximately $55 \mathrm{~N}$ [12 lbf]. There is no ability to vary applied radial load on this rig, which limits the steady state test data to lightly loaded conditions. A precision load cell is mounted close to the bearing center due to space limitations. This close coupling of the load cell also limits the range of reaction torque and power loss that can be measured on this rig. The entire test rig is enclosed in a pressure vessel. This pressure vessel can be evacuated to 0.1 atmospheres and pressurized to 48 

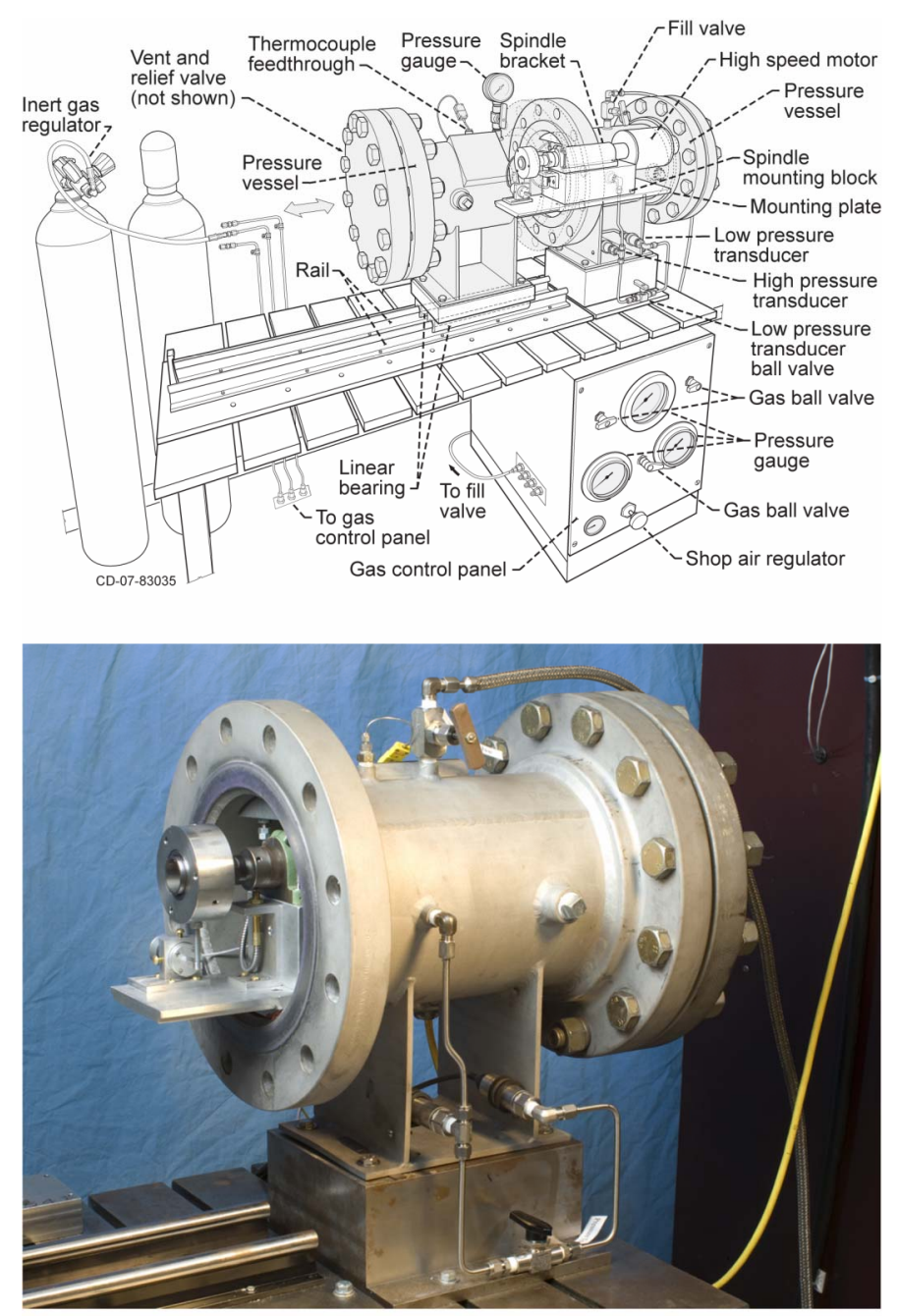

Figure 5.-The high pressure rig.

atmospheres. A variety of inert gases can be used in this test rig to investigate gas property effects on foil bearing performance. For the current test program only nitrogen has been used as a foil bearing lubricant. Generation III foil journal bearings with uncoated Inconel top foils running against conditioned PS304 high temperature solid lubricant coated shafts were used in this study. The test procedure used on this rig includes a preliminary conditioning of the PS304 coated shaft, which includes running a series of start-stop cycles under radial load. High temperature start-stop cycles cannot be run on this rig, which therefore limits the load capacity coefficient to approximately $0.19 \mathrm{mN} /\left(\mathrm{mm}^{3} \mathrm{krpm}\right)$ [0.7 lbf/(in. $\left.\left.{ }^{3} \mathrm{krpm}\right)\right]$. The test procedure for this rig includes using one fixed, "deadweight" load, setting the chamber test gas and pressure, and accelerating to maximum speed as quickly as possible. Steady state data is then collected by reducing speed in set increments and recording reaction torque until the minimum power loss level is found. Figure 6 contains reduced data showing the similarity of steady state and startup data for the high pressure rig.

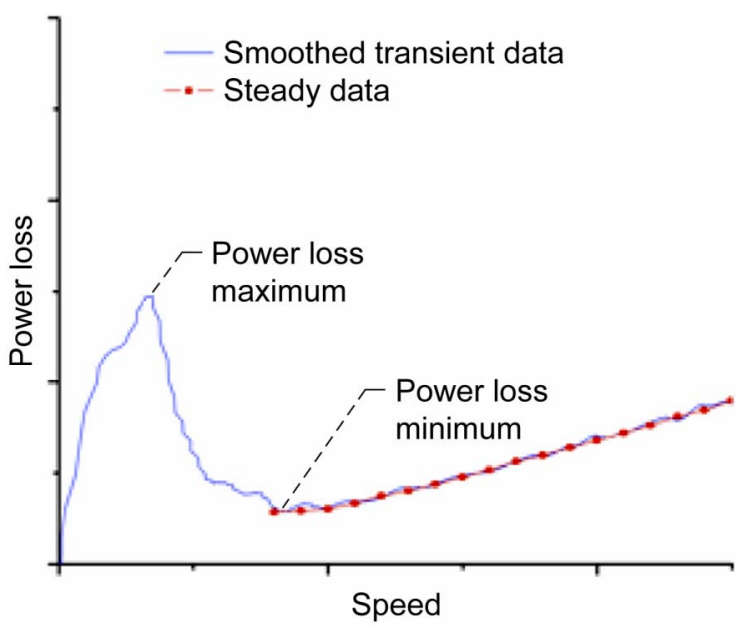

Figure 6.-Typical transient and steady state data from the high pressure rig.

\section{Experimental Results}

Experimental results obtained from the ambient pressure rig are shown in figures 7, 8, and 9. Figure 7 presents specific power loss as a function of applied load for a series of rotational speeds. The conditions in the test chamber, bearing cavity, are ambient temperature, $25^{\circ} \mathrm{C}$, and pressures ranging from 0.1 to 2.5 atmospheres. The performance of the bearing at 0.1 atmosphere pressure is characterized by (1) low load capacity, (2) small operating range, and (3) non-linear load versus power loss trend. Beginning with the 0.7 atmosphere bearing performance and continuing through the 2.5 atmosphere performance the operating range and load capacity of the bearing continues to increase with increasing pressure. In addition, the load versus power loss trend begins to show two phases. The first phase is a gradual, nearly linear, trend followed by a sharp, non-linear, trend in this characteristic as the load capacity point is approached. The foil bearing performance trends as a function of ambient pressure can be summarized such that for increasing pressure the load capacity and linear operating range increases.

Figure 8 presents power loss as a function of applied load for two different temperatures, 200 and $400{ }^{\circ} \mathrm{C}$, at 1.0 atmosphere of pressure. The trend shown in this figure indicates that foil bearing load capacity decreases with increasing temperature. Since, for a gas, absolute viscosity increases with temperature, this result is often considered somewhat contradictory when compared to traditional hydrodynamic theory. Typically, hydrodynamic pressure and load capacity increase proportionally with viscosity. These results, which are consistent with previously published data on compliant foil bearings, point primarily toward a softening of the compliant foundation due to thermal effects on the Inconel $\mathrm{X}-750$ modulus. An additional impact is the reduced lubricant density at higher temperatures that reduces the massflow through the bearing. With reduced massflow but similar rates of shear in the gas film, heating is increased and a thermal run- 

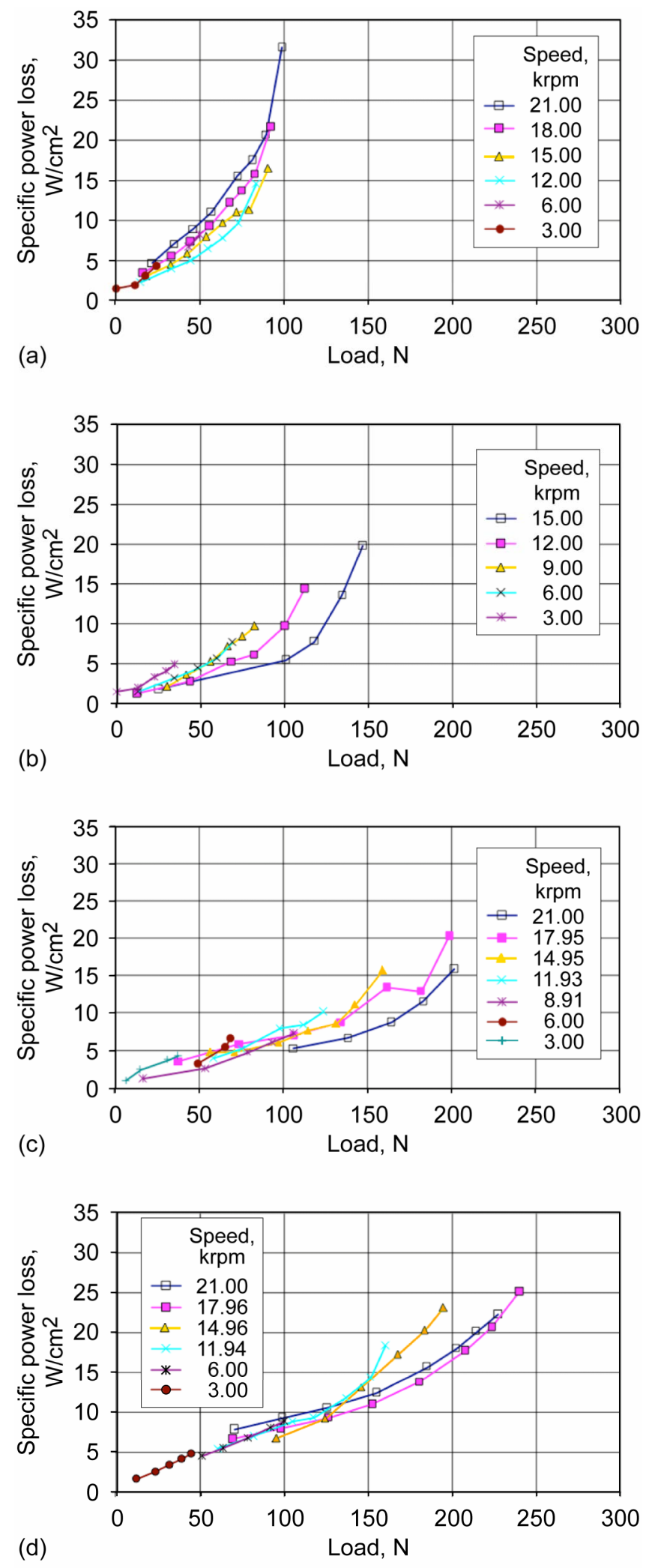

Figure 7.-Foil bearing performance in air at ambient temperature and various pressures. (a) $0.1 \mathrm{~atm}$.

(b) $0.7 \mathrm{~atm}$. (c) $1.5 \mathrm{~atm}$. (d) $2.5 \mathrm{~atm}$.
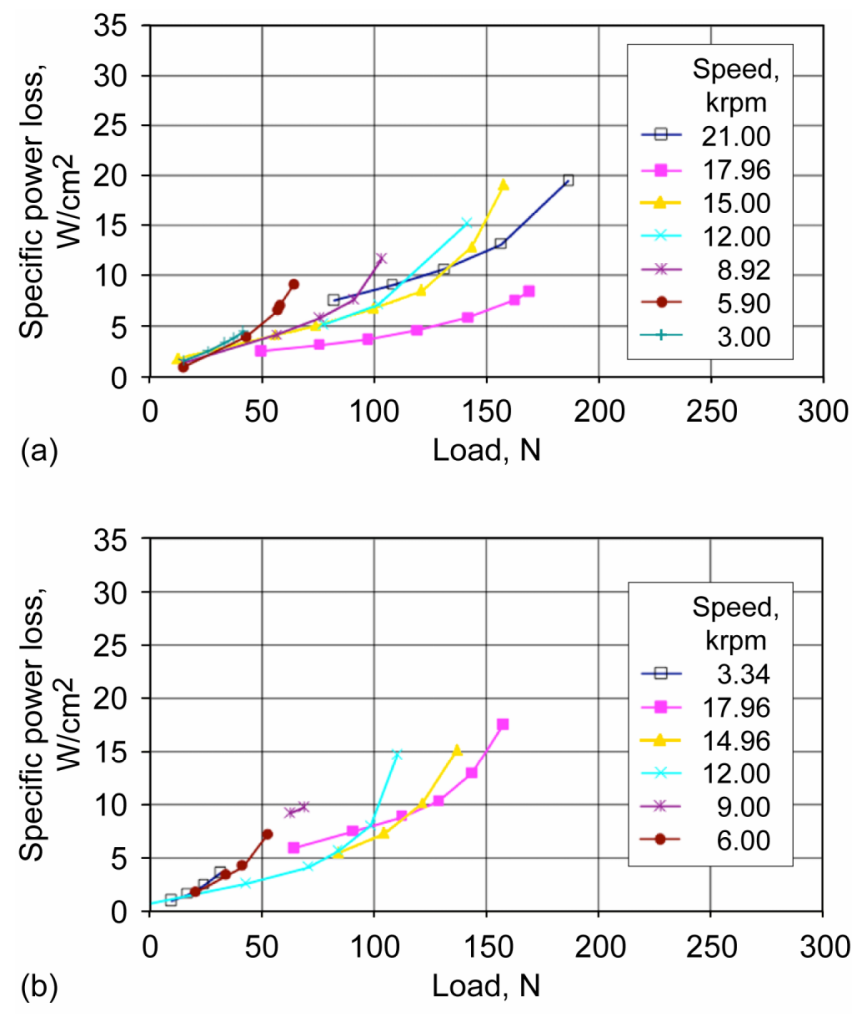

Figure 8.-1.0 atmosphere ambient pressure foil bearing performance in air at two temperatures. (a) $200{ }^{\circ} \mathrm{C}$.

(b) $400^{\circ} \mathrm{C}$.

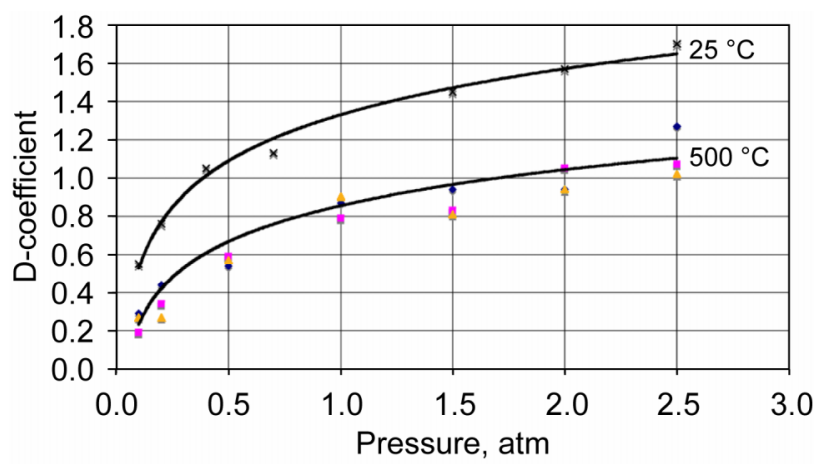

Figure 9.-Load capacity coefficient versus pressure for $25^{\circ} \mathrm{C}$ and $500^{\circ} \mathrm{C}$.

away load capacity failure is more likely to occur at lower loads for a high temperature gas. Figure 9 presents a compilation of foil bearing load capacity coefficient spanning the range of test data from 0.1 to 2.5 atmospheres and 25 to $500{ }^{\circ} \mathrm{C}$. The trend shows an increase in load capacity with increasing bearing cavity pressure. Below approximately 0.5 atmospheres of pressure the load capacity drops off dramatically, which is indicative of a starved bearing condition. Under these conditions there simply are not enough molecules of lubricant to support the load. At higher pressures load capacity increases with increasing pressure. 

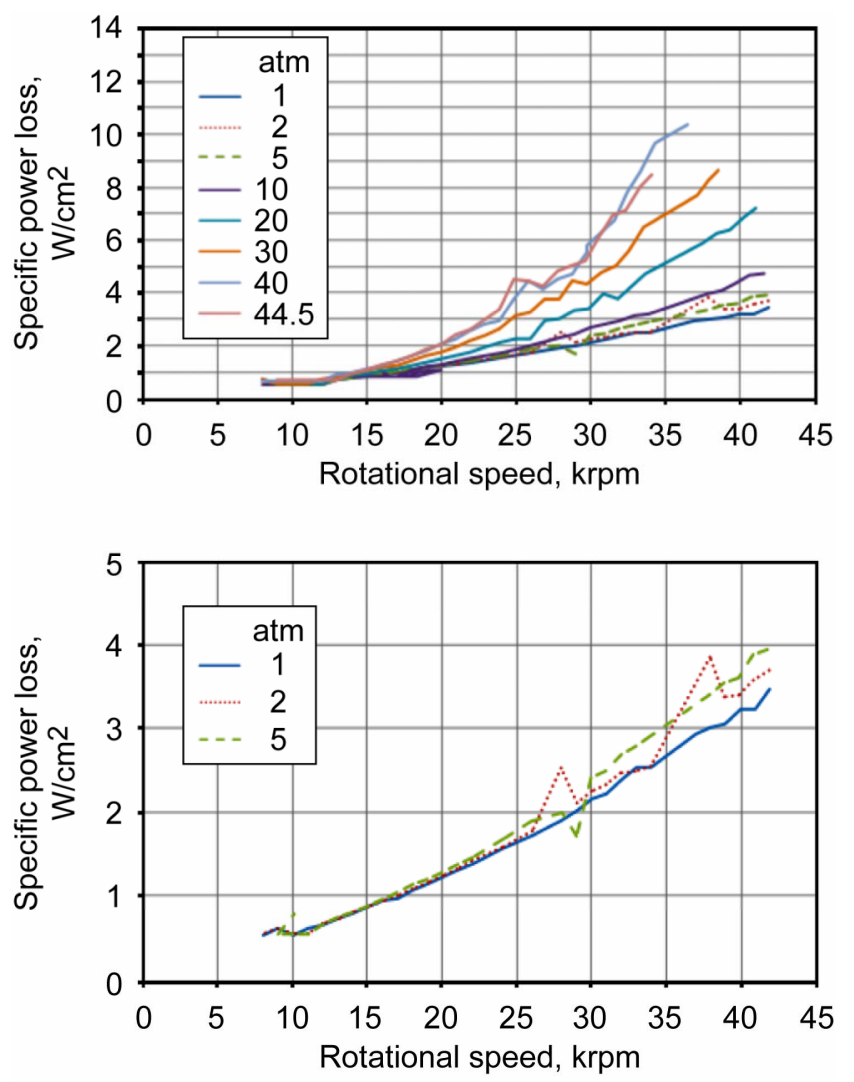

Figure 10.-The lightly loaded region of the foil bearing performance map from 1 to 44.5 atmosphere ambient pressure. Applied load $=14 \mathrm{~N}$.

Lightly loaded bearing performance data is presented in figure 10. The data show specific power loss versus rotational speed for ambient pressures up to 48 atmospheres, $25^{\circ} \mathrm{C}$, nitrogen gas, and constant load of $14 \mathrm{~N}(3.1 \mathrm{lbf})$. The trends converge at the minimum power loss point, but diverge with increasing speed. The overall trend shows an increase in bearing power loss with increasing pressure. This appears to be an opposite trend to that discussed previously with regard to the temperature effects. In this instance, the increased lubricant density appears to be detrimental to the performance and power loss of the bearing. While no bearing failures occurred due to the high pressures, and in fact the absolute power loss remained low compared to the power loss at load capacity, these contrary trends require further investigation. Although, the two test rigs utilized in this study have a capability range with some overlap, it is critical to the complete understanding of these trends that the entire foil bearing performance map from load capacity to the very lightly loaded regime be tested in a consistent manner.

\section{Conclusions}

The experimental results presented herein demonstrate the performance variability of foil journal bearings with respect to load, speed, ambient temperature, and ambient pressure. While these results encompass only a small range of potential foil bearing applications they do provide initial design guidance to designers of future microturbines. Foil journal bearings exhibit an increase in load capacity with increasing pressure and a decrease in load capacity with increasing temperature. These results are consistent with the fact that the compliant foundation is softened at elevated temperatures and that foil bearings typically fail or reach load capacity due to a thermal overload. The reduced massflow through the bearing at low pressures and high temperature therefore leads to reduced load capacities. Foil bearings show robust operation down to 0.5 atmospheres of ambient pressure. Below this pressure level it appears as though foil bearing operation would be more challenging.

\section{References}

1. Blok, H. and VanRussom, J., "The Foil Bearing-A New Departure in Hydrodynamic Lubrication," Lubrication Engineering, 1953.

2. Mason, L., "A Power Conversion Concept for the Jupiter Icy Moons Orbiter," AIAA-2003-6007.

3. DellaCorte, C., Valco, M.J., "Load Capacity Estimation of Foil Air Journal Bearings for Oil-Free Turbomachinery Applications," NASA-TM-209782, 2000.

4. DellaCorte, C., Radil, K., Bruckner, R.J., Howard, S.A., "A Preliminary Foil Gas Bearing Performance Map," NASA/TM-2006-214343, 2006.

5. DellaCorte, D., Lukaszewicz, V., Valco, M.J., Radil, K.C., Heshmat, H., "Performance and Durability of High Temperature Foil Air Bearings for Oil-Free Turbomachinery," NASA/TM-2000-209187, March 2000.

6. DellaCorte, C., "Composition Optimization of $\mathrm{Cr}_{3} \mathrm{C}_{2}$ Based Solid Lubricant Coatings for Foil Gas Bearings at Temperatures to $650^{\circ} \mathrm{C}$," NASA CR-179649, July 1987.

7. DellaCorte, C., Zaldana, A.R., Radil, K.C., "A Systems Approach to the Solid Lubrication of Foil Air Bearings for Oil-Free Turbomachinery," NASA/TM-2002211482.

8. Heshmat, H., Shapiro, W., Gray, S., "Development of Foil Journal Bearings for High Load Capacity and High Speed Whirl Stability," Transactions of the ASME Journal of Lubrication Technology, vol. 104, no. 2, pp. 149-156, April 1982.

9. DellaCorte, C., Valco, M.J., "Oil-Free Turbomachinery Technology for Regional Jet, Rotorcraft, and Supersonic Business Jet Propulsion Engines," Proceedings of the 2003 International Society of Airbreathing Engines Conference, Cleveland, Ohio, September 2003, ISABE Paper \#2003-1182.

10. Suriano, F.J., "Gas Foil Bearing Development Program," U.S. Airforce Report \#AFWAL-TR-81-2095. 
11. Valco, M.J., DellaCorte, C., "Emerging Oil-Free Technology for Military Propulsion and Power Applications," Prodeedings of the ARMY Sciences Conferences, Ft. Lauderdale, FL, February, 2003.

12. Dykas, B., Howard, S.A., "Journal Design Considerations for Turbomachine Shafts Supported on Foil Air Bearings," Tribology Transactions, vol. 47, no. 4, pp. 508-516, 2004.

13. Salehi, M., Swanson, E., Heshmat, H., "Thermal Features of Compliant Foil Bearings-Theory and Experiment," Journal of Tribology, volume 123, issue 3, pp. 566-571, July 2001.
14. Radil, K.C., Zeszotek, M., “An Experimental Investigation Into the Temperature Profile of a Compliant Foil Air Bearing," NASA/TM-2004-213100.

15. Radil, K.C., Howard, S.A., Dykas, B., "The Role of Radial Cearance on the Performance of Foil Air Bearings," NASA/TM-2002-211705. 


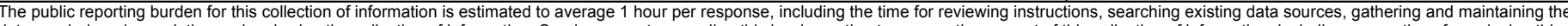

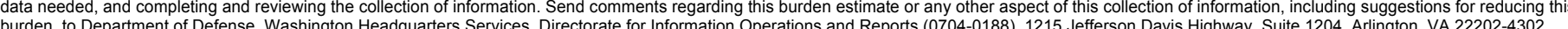

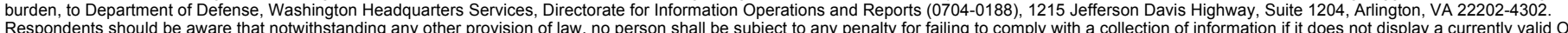

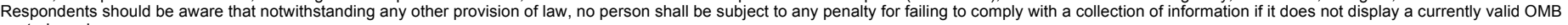

PLEASE DO NOT RETURN YOUR FORM TO THE ABOVE ADDRESS

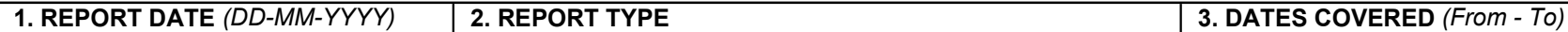

01-05-2008

\section{TITLE AND SUBTITLE}

Technical Memorandum

Compliant Foil Journal Bearing Performance at Alternate Pressures and Temperatures

5a. CONTRACT NUMBER

5b. GRANT NUMBER

5c. PROGRAM ELEMENT NUMBER

6. AUTHOR(S)

Bruckner, Robert, J.; Puleo, Bernadette, J.

5d. PROJECT NUMBER

5e. TASK NUMBER

5f. WORK UNIT NUMBER

WBS 877868.02.07.03.01.01

7. PERFORMING ORGANIZATION NAME(S) AND ADDRESS(ES)

National Aeronautics and Space Administration

8. PERFORMING ORGANIZATION

John H. Glenn Research Center at Lewis Field

REPORT NUMBER

E-16512-1

Cleveland, Ohio 44135-3191

9. SPONSORING/MONITORING AGENCY NAME(S) AND ADDRESS(ES)

National Aeronautics and Space Administration

Washington, DC 20546-0001

\section{SPONSORING/MONITORS ACRONYM(S) \\ NASA}

11. SPONSORING/MONITORING REPORT NUMBER

NASA/TM-2008-215219

\section{DISTRIBUTION/AVAILABILITY STATEMENT}

Unclassified-Unlimited

Subject Categories: 07 and 37

Available electronically at http://gltrs.grc.nasa.gov

This publication is available from the NASA Center for AeroSpace Information, 301-621-0390

\section{SUPPLEMENTARY NOTES}

\section{ABSTRACT}

An experimental test program has been conducted to determine the highly loaded performance of current generation gas foil bearings at alternate pressures and temperatures. Typically foil bearing performance has been reported at temperatures relevant to turbomachinery applications but only at an ambient pressure of one atmosphere. This dearth of data at alternate pressures has motivated the current test program. Two facilities were used in the test program, the ambient pressure rig and the high pressure rig. The test program utilized a $35 \mathrm{~mm}$ diameter by $27 \mathrm{~mm}$ long foil journal bearing having an uncoated Inconel X-750 top foil running against a shaft with a PS304 coated journal. Load capacity tests were conducted at $3,6,9,12,15,18$, and $21 \mathrm{krpm}$ at temperatures from 25 to $500{ }^{\circ} \mathrm{C}$ and at pressures from 0.1 to 2.5 atmospheres. Results show an increase in load capacity with increased ambient pressure and a reduction in load capacity with increased ambient temperature. Below one-half atmosphere of ambient pressure a dramatic loss of load capacity is experienced. Additional lightly loaded foil bearing performance in nitrogen at $25^{\circ} \mathrm{C}$ and up to 48 atmospheres of ambient pressure has also been reported. In the lightly loaded region of operation the power loss increases for increasing pressure at a fixed load. Knowledge of foil bearing performance at operating conditions found within potential machine applications will reduce program development risk of future foil bearing supported turbomachines.

\section{SUBJECT TERMS}

Foil bearings; Gas bearings; Journal bearings; Turbo generators; Turbomachinery; Hydrodynamics

\begin{tabular}{|l|l|l|l|l|l|}
\hline \multicolumn{2}{|l|}{ 16. SECURITY CLASSIFICATION OF: } & $\begin{array}{l}\text { 17. LIMITATION OF } \\
\text { ABSTRACT }\end{array}$ & $\begin{array}{l}\text { 18. NUMBER } \\
\text { OF } \\
\text { PAGES }\end{array}$ & $\begin{array}{l}\text { 19a. NAME OF RESPONSIBLE PERSON } \\
\text { STI Help Desk (email:help } @ \text { sti.nasa.gov) }\end{array}$ \\
\cline { 1 - 2 } $\begin{array}{l}\text { a. REPORT } \\
\text { U }\end{array}$ & $\begin{array}{l}\text { b. ABSTRACT } \\
\text { 19b. TELEPHONE NUMBER (include area code) }\end{array}$ & $\begin{array}{l}\text { c. THIS } \\
\text { PAGE } \\
\text { U }\end{array}$ & UU & 14 & $301-621-0390$ \\
\end{tabular}



